«Epistemological studies in Philosophy, Social and Political Sciences», 2018, 1 (1-2)

ISSN 2618-1274 (print) ISSN 2618-1282 (online)

УДК 327

Received 04 August 2017

Received in revised form 11 September 2017

Mykytchuk N., Hanko V.

Accepted 18 October 2017

\title{
ENERGY FACTOR IN CHINA-TURKMENISTAN RELATIONS
}

The article is devoted to an assessment of the place and role of the energy factor in ChinaTurkmenistan relations, identification of the main areas, results and prospects of bilateral energy cooperation.

Keywords: the energy factor, China-Turkmenistan relations, the PRC's foreign strategy resource potential of Turkmenistan energy cooperation.

\section{Микитчук Н., Ганько В., Енергетичний фактор у відносинах Китаю і Туркменістану}

Стаття присвячена комплексному аналізу ролі та місця енергетичного фактору у відносинах Китаю та Туркменістану, визначенню основних напрямків, досягнень та перспектив двосторонньої енергетичної співпраці.

Ключові слова: енергетичний фактор, відносини між Китаєм та Туркменістаном, зовнішня стратегія КНР, ресурсний потенціал Туркменістану, енергетичне співробітництво.

\section{Микитчук Н., Ганько В., Энергетический фактор в отношениях Китая и Туркменистана}

Статья посвящена комплексному анализу роли и места энергетического фактора в отношениях Китая и Туркменистана, определению основных направлений, дострижений и перспектив двустороннего энергетического сотрудничества.

Ключевые слова: энергетический фактор, китайско-туркменские отношения, внешняя стратегия КНР, ресурсный потенциал Туркменистана, энергетическое сотрудничество.

Problem statement. At present, the People's Republic of China in the Central Asian vector of foreign policy is interested in finding sources of energy resources. This is due to China's growing economic growth rate. Turkmenistan, with $17.4 \%$ of the world's natural gas reserves, is the most suitable partner for China [1]. The relevance of the topic lies in the fact that energy resources are one of the most important factors in international relations. They also play a strategic role in implementing the state policy of any country. Therefore, interest in the problems of energy security is increasing all over the world. The study of energy policy in bilateral relations between China and Turkmenistan is important not only for determining China's energy security, but also serves as a basis for predicting China's global role in the 21 st century. Consideration of China's energy cooperation with other countries also has an obvious significance for the completeness of the concept of the content of the current stage of ensuring global energy security.

The goal of the research is an assessment of the place and role of the energy factor in ChinaTurkmenistan relations, identification of the main areas of bilateral energy cooperation, and research on methods for its implementation.

Review of used sources and literature. The topic of bilateral relations between the People's Republic of China and Turkmenistan in the field of energy is sufficiently investigated. In particular, such scholars as A. Strokov, V. Paramonov give a clear description of the main tendencies of their main tendencies. It is also worth noting the works of O. Stolpovsky and the articles of I. Ipolitov, which give a logical structured idea of the development of China-Turkmen relations. Many electronic sources were used during the writing process, including the official CNPC site, the Nebit-gaz electronic newspaper of 
Turkmenistan's oil and gas complex, the official website of the President of Turkmenistan etc.

In international relations, the energy factor plays a key role, therefore, in the context of growing energy interdependence, states seek to ensure energy security at the regional and global levels. In recent years, China has played an important role in ensuring global energy security. On the one hand, China's growing energy demand has aggravated international energy competition. On the other hand, the growing role of China in the global energy industry contributes to international energy cooperation. China's energy security is closely linked to the possibility of global energy security.

In the middle 1990s, China displayed the first flickers of interest in the Central Asian fuel and energy complex, which has been steadily growing since that time along with Beijing's interest in other spheres of the region's economy. In the latter half of the last decade of the 20th century, the project activities of China and Chinese companies in the Central Asian energy segment were concentrated in Kazakhstan's oil and gas sector. In the early 21 st century, however, this interest began gradually spreading to the rest of the region to become diversified by the industry's branches. Today, China is showing a lot of interest in the oil and gas of Kazakhstan and Turkmenistan and in the nuclear power production of the former [2]. China is paying enough attention to the fuel and energy complexes of the rest of the region to promote its economic and political interests in each of the states and the region as a whole [3].

Early in the 21st century, Central Asia's importance as one of China's foreign economic factors was boosted by the changed economic, energy, and geopolitical factors. In the wake of $9 / 11$, the region, which had so far remained in the backwater of world development, found itself in the center of hectic political activities. Beijing augmented its economic presence in Central Asia: it intensified its project and investment involvement, even though this was still limited to the region's mineral and fuel riches. Chinese producers expanded their presence in the Central Asian markets; larger loans started flowing into the Central Asian economies. This meant that
Beijing identified the economy as a linchpin of its Central Asian strategy. The Central Asian countries, in turn, learned to look at China not as an important trading partner, but as a strategic investor/creditor for their economies.

1.1 China's rapidly growing economic presence in the region and its bilateral and multilateral economic relations (including in the fuel and energy complex) with the local states are still far from the ideal and from historically justified cooperation patterns; they hardly fit China's long-term interests or those of the Central Asian countries and Russia.

Domestic policy. China's general strategy is geared toward boosting the efficiency of the planned and centralized state administration and management of its ramified and dynamically developing economy, while liberalizing economic activities at home. This means that the Chinese fuel and energy complex is intended to ensure consistent development of all the economic segments, social and economic stability, and stronger military and political might. China's energy policy was and is concentrated on the following: 1) stage-by-stage development of the domestic raw material base of the national fuel and energy complex; 2) its accelerated technological modernization; 3) diversification of national power production by using all types of energy sources [4].

Foreign policy. China's external energy policy boils down to two main areas: attracting foreign investment for the development of the domestic energy industry and the active participation of national capital in the exploration and development of oil fields abroad [5]. The first way involves establishing partnerships with the largest energy TNCs that have significant capital, modern technologies and rich field work experience. The second way leads to aggravation of competition with the largest energy TNCs, which currently occupy the best segments of the international energy market.

China is seeking a place among the key players on the global economic and political scene. Applied to the energy sphere, the above means that Beijing should protect its economic interests and its influence in the global and regional 
energy markets by acquiring firm positions in long-term contacts with fuel-rich countries (the Central Asian countries included) to guarantee a consistent inflow of raw materials into its fuel and energy complex. Today, its interests are concentrated on hydrocarbons; tomorrow they will spread to uranium. This is not an end in itself, but rather the country's readiness to cooperate with other countries, particularly its neighbors, in order to guarantee China's strategic interests in the economic, security, and political spheres.

The fact that this strategy underestimates the fundamental importance of the Eurasian heartland and the potential of strategic partnership with the Russian Federation and Central Asia can be described as one of the main faults of China's strategic course. This, however, is largely predetermined by Russia's and Central Asia's policy in the energy sphere, which is still limited to the interests of national companies and geared toward larger fuel exports [6]. This explains why China regards Russia and the Central Asian countries as unreliable and temporary allies rather than strategic partners; in the energy sphere, their role is limited to fuel and raw material supplies. The interests of Russia and the Central Asian countries (including in the energy sphere) are threatened by the factors described above rather than by Chinese policy per se. Energyand rawmaterial-related rivalry between China and Russia and the Central Asian countries cannot be totally excluded.

Turkmenistan is by right one of the largest energy superpowers. The reserves of natural gas here are over 20 trillion $\mathrm{m} 3$, oil - about 20 billion tons [7]. In 2017, Turkmenistan confirmed its status in the world arena by a significant event in its scale - the chairmanship of the Energy Charter Conference [8]. This honorary status was unanimously awarded to Turkmenistan in November last year as one of the most carbonrich states in the world. The event will set the direction in the development of the Charter and will be the main discussion platform on aspects of international cooperation in the energy sector. In the role of chairman, Turkmenistan will rely on its rich experience in working with the Charter. In particular, in December 2014 the 98
Ministry of Foreign Affairs of Turkmenistan and the Charter Secretariat successfully held an international forum «Reliable and stable transit of energy carriers», the main agenda of which was discussion of the possibilities of energy trade in the region and its role in diversifying sources and supply routes [9].

The reserves of Turkmenistan's hydrocarbon resources greatly exceed domestic demand. That is why the development of export of resources and access to international markets are at the core of the country's economic strategy. The national oil and gas development program is aimed at increasing the annual production of natural gas to 250 billion cubic meters, of which 180 billion will be available for export. Foreign investments and participation of international oil companies will play a leading role in the exploration of offshore fields in the Turkmen sector of the Caspian Sea. Currently, foreign companies account for about $56 \%$ of oil production and $28 \%$ of gas [10]. At the same time, Japanese companies will actively invest in equipment for processing fuel and petrochemical products [11]. Natural gas ranks first place in terms of Turkmenistan's export potential. East is the route of the former Silk Road, which provides growing demand from the Chinese industry. Already today, the capacity of the pipeline through Uzbekistan and Kazakhstan to China is 55 billion $\mathrm{m} 3$ per year [12]. The opening of the fourth line will increase the carrying capacity to $85 \mathrm{bcm}$ per year. 2 other threads, with a total capacity of 20 billion cubic meters, are associated with industrial and human settlements in Iran [13].

The country's export potential is rapidly gaining momentum. The length of the TurkmenistanAfghanistan-Pakistan-India gas pipeline (TAPI) under construction will be approximately 1,800 $\mathrm{km}$. The throughput capacity will be about 33 billion cubic meters of gas per year. The project is an important element not only in the economic development of Turkmenistan, but also in the countries along the pipeline route, providing them with reliable and abundant supplies of the cleanest and most efficient fuel. TAPI can be seen as a long-term investment. The cost of the project is $\$ 10$ billion. Turkmenistan will cover $85 \%$ of 
the cost of the pipeline, $15 \%$ of the costs will be divided equally between Afghanistan, Pakistan and India. An important role in financing will be played by loans in the amount of $\$ 1$ billion from the Asian Development Bank and \$ 500 million from the Islamic Development Bank. In addition, a number of international companies, including Siemens, will also provide credit support to the project [14].

In addition to the opportunities for raw materials exports, Turkmenistan uses natural gas to generate additional environmentally friendly electricity and heat that can provide not only the domestic needs of the country, but also neighboring countries. Over the past decade, the country has doubled its electricity production to 23 billion $\mathrm{kW} / \mathrm{h}$. This was the first stage in the implementation of a comprehensive plan for the modernization of the country's electric power potential, the total volume of allocated investments of which amounts to $\$ 5$ billion.

Moreover, by 2020, 14 gas turbine power plants of the combined cycle will be put into operation. This will increase the production of electricity to 27.4 billion $\mathrm{kW} / \mathrm{h}$ per year, and the volume of exports will increase to 6 billion $\mathrm{kW} / \mathrm{h}$. By 2030, the volume of electricity produced will grow to 35.5 billion. The current export destinations are Iran and Afghanistan, but there is potential for reaching not only neighboring countries, but also to Pakistan, Turkey and Armenia. And, finally, the rich oil deposits of Turkmenistan. Oil and oil products occupy the second and third place in the country's export table. Only for the period from 2012 to 2014, 18 million tons of oil and 16 million tons of oil products were exported [15].

In these latter days, Turkmenistan is determined to develop technologies for obtaining energy from renewable sources. At the recent exhibition EXPO2017 President Gurbanguly Berdimuhamedov said that the country is implementing projects on sustainable development of the environment, modernizing the basic sectors of the economy with the use of advanced technologies in the context of environmental safety standards. Thematic core of the exposition was scientific developments, innovative projects implemented and implemented in the field of energy [16].
In order to study the potential of renewable energy sources, improve scientific and technical research, and widely introduce appropriate scientific developments and innovations into the production, in 2014 the Gyun Institute (the Sun) and the Physico-Mathematical Institute of the Academy of Sciences of Turkmenistan were merged and based on them The Institute of Solar Energy of the Academy of Sciences of Turkmenistan was established. Taking into account the current situation, one of the most urgent aspects is the training of engineers with knowledge and skills in the design, design and operation of devices operating on the basis of RES. In this regard, many universities in the CIS countries began to train specialists in this field. As for Turkmenistan, from 2014-2015 academic year on the basis of the State Energy Institute of Turkmenistan engineers are trained in RES specialty «non-traditional and renewable energy sources».

Within the framework of cooperation with the OSCE Center in Ashgabat from 2017, the project «Support of the Scientific Center on the basis of the State Energy Institute of Turkmenistan in the city of Mary» was launched. Its main task is to assist in matters related to the development of scientific cooperation, primarily with a view to conducting relevant research in the field of renewable energy sources [17].

Economic relations between Turkmenistan and China are characterized by the absolute dominance of cooperation in the sphere of the extraction and sale of energy resources. Before the advent of this direction, the economic interaction between the two countries was insignificant. In the 1990's. - the first half of the first decade of the 21 st century. Sino-Turkmen trade accounted for no more than $2 \%$ of China's total trade with the countries of the Central Asian region (total within $\$ 110$ million) [18].

The transition of Sino-Turkmen economic cooperation to a fundamentally new level emerged during President Niyazov's visit to Beijing in April 2006. At that time, a number of treaties were signed, including the General Agreement on Cooperation of the Chinese National Oil and Gas Corporation (CNPC) with the Ministry 
of Oil and Gas Industry of Turkmenistan. According to this agreement, the parties agreed on the construction of the Turkmenistan-China gas pipeline, purchases of Turkmen gas by China in the amount of up to 30 billion cubic meters per year for 30 years and joint development of deposits on the right bank of the Amu Darya [19].

The construction of the Trans-Asian gas pipeline (Central Asia-China) on the route Turkmenistan-Uzbekistan-Kazakhstan-China began in August 2007 on the basis of bilateral agreements between China and these states. It was conducted with funds allocated in the form of loans from the State Development Bank of China and direct investments by CNPC [20].

On June 24, 2009, a delegation of high-ranking officials from China headed by Deputy Premier Li Keqiang visited Ashgabat. Following the meeting with Berdymukhamedov, the parties signed a package of documents on cooperation in the fuel and energy sector, including the purchase and sale of natural gas. According to the concluded agreements, Turkmenistan undertook to supply gas to China in 2009 to 30 billion cubic meters a year after the commissioning of the first stage of the Trans-Asian Gas Pipeline. An agreement was also signed on the extradition of Turkmenistan by the Development Bank of China to a loan of \$ 4 billion. on the development of gas deposits of the South Iolotan Group (Galkynysh) [21].

During his visit to China in November 2011, G. Berdymukhamedov signed an agreement according to which the volume of Turkmen gas supplies to China will be additionally increased by 25 billion cubic meters per year - up to 65 billion. According to the Turkmen authorities, this level of gas supply in China will come out by 2021 [22]. In September 2013, during the visit of the Chairman of the People's Republic of China Xi Jinping to Turkmenistan between the Turkmengaz Concern and the State Development Bank of China, cooperation agreements were signed on a new stage in the development of Galkynysh. Among them was an agreement on the construction by CNPC of a new gas processing complex with a capacity of 30 billion cubic meters per year (that is, in the amount of up to 60 billion per year), and also about the Sino100
Turkmen cooperation in financing the second stage [23].

Over the past five years, China has been Turkmenistan's largest trading partner. According to data for 2016, about 40 enterprises with participation of Chinese capital work in Turkmenistan, about 70 investment projects were registered for a total of more than 4 billion US dollars and 2.3 billion yuan [24].

Companies from China are represented in the oil and gas and telecommunications spheres, transport, agriculture, textile, chemical and food industries, healthcare and construction. Companies in China have implemented a number of major projects in the gas sector. In particular, CNPC, the largest Chinese oil and gas company, has a number of large projects with the state concern Turkmengaz. Since 2008, according to the project on exploration and development of gas on the right bank of the Amudary River, the two largest Central Asian-China (TurkmenistanUzbekistan-Kazakhstan-China) gas pipelines from zone A and B operate in the Bagtyyarlyk contract area since 2007 and 2014, respectively. After the introduction of the second gas processing plant, the total production capacity of the two plants reached 150 billion a year. [25]. In May 2014, the commissioning of the third thread $\mathrm{C}$ with a diameter of $1219 \mathrm{~mm}$ and a capacity of 25 billion cubic meters per year began. Thus, three lines are able to supply up to 55 billion cubic meters of gas per year to China [26].

In 2015, with regard to the foothill zone to the east of the right bank of the Amu Darya River, priority prior reconnaissance has developed. As a result of a pilot exploration well in two layers, gas inflows of more than 1 million $\mathrm{m} 3$ were obtained in the formation; in the Gokmiyar formation, successful exploration wells in Upper Jurassic limestones and Middle and Lower Jurassic sandstones were successfully completed; in the formation, the appraisal well subsequently confirmed the size of the gas reservoir reserves, having formed two gas zones with a stock size of 100 billion $\mathrm{m} 3$ of Khodjagurluk-Gyokmiyar in the south and in the north.

On September 14, the Bota-Tangygyy-Uzyngui gas fields were launched in the framework of the 
Amudarya River project in Turkmenistan. Their combined capacity is 1 billion $\mathrm{m} 3$ per year. In addition, key projects such as the reconstruction and expansion of production capacity of 8 billion $\mathrm{m} 3$ /year at the Ablock of the Amudarya River have been launched, the projects of the gas gathering and transport system at the fields of Girsan, BotaTangygyy-Uzyngui, Ojarly-Sandykly in Block B [27] .In 2014, the Corporation, as a general contractor, commissioned a turn-key project to build production capacity of 10 billion cubic meters of commercial gas a year at the Galkynsh gas field in Turkmenistan.

In addition to gas production, the corporation provides engineering and technical services in oil fields, including well drilling, well logging, construction of ground facilities for oil and gas fields, etc. SINOPEC also operates in the same field. It is engaged in the repair and maintenance of wells in the gas and oil fields Shatlyk, Dovletabad, Goturdepe, etc. Along the way, Chinese experts collect information on the geological conditions and hydrocarbon resources of Turkmenistan [28].

In 2012, projects for the collection and transport system at the Metejan gas field and the construction of the gas processing plant Galkynysh and its component facility were successfully implemented. In September 2013, the corporation with Turkmengaz Concern signed a general contract agreement for the construction of a turn-key project to build a commercial gas production capacity of 30 billion cubic meters / year. on the Galkynysh gas field, the construction and launch of which are planned for 2018. In 2014, the Corporation, as a general contractor, commissioned a turn-key project to build production capacity of 10 billion cubic meters of commercial gas a year at the Galkynsh gas field in Turkmenistan.

In the next three months, work will begin in Afghanistan on the implementation of the Turkmenistan-Afghanistan-Pakistan-India (TAPI) gas pipeline. The other day CNPC declared China's readiness to support the construction of the TAPI gas pipeline at the conference «Oil and Gas of Turkmenistan-2017»: «CNPC is ready to expand the scope of partnership with Turkmenistan in the development of gas transportation infrastructure. The company is also ready to assist Turkmenistan in the construction of the TAPI (Turkmenistan-Afghanistan-PakistanIndia) gas pipeline, as well as the Trans-Caspian gas pipeline project, if implemented, «noted the CNPC CEO [29].

To sum up, at present Turkmenistan and China have strong economic relations based mainly on the purchase of Turkmen gas, Chinese investments in the development of gas production and gas transportation infrastructure. Both sides are interested in developing bilateral relations and extracting maximum benefits from them. By 2011, 37 enterprises with the participation of Chinese capital were registered and operated in Turkmenistan, 57 investment projects worth over $\$ 4.1$ billion were executed by them and 2.328 trillion yuan [30]. In view of the cooperation between Turkmenistan and China on energy resources, the bilateral trade has doubled annually over the past three years. Following the results of 2011, when gas supplies to China acquired a large-scale nature, the cooperation of the two countries in the fuel and energy sector fully reflected on bilateral trade and occupied the dominant position in it. However, recently there have been obvious problems with regard to the PRC and Turkmenistan.

First, Turkmenistan is now experiencing the worst economic crisis in 25 years. It is explained mainly by the dependence on revenues from gas sales, which prices fell sharply in the last three years. According to official data, economic growth in the country amounted to $6.7 \%$ in 2015 (10.3\% in 2014), and the national currency of manat was devalued by $19 \%$ (free sale of foreign currency to citizens of the country was curtailed). Against the backdrop of inflation of about $8 \%$ per annum, there was a significant increase in prices and began to show interruptions in food security. The growth of Turkmenistan's GDP in 2015 was $6.7 \%$ [31] Besides, the other day the final decision was made not to build the fourth line of the gas pipeline, according to which additional volumes of gas from Turkmenistan were to go to the China.

It was assumed that almost 30 billion cubic meters of gas would be delivered annually through 
the D pipeline to the Middle Kingdom. Three existing lines of the gas pipeline $(\mathrm{A}, \mathrm{B}, \mathrm{C})$ go from Turkmenistan to China through Uzbekistan and Kazakhstan. To include all Central Asian states in Beijing, they decided to pull the pipeline through Uzbekistan, Tajikistan and Kyrgyzstan.

However, by the end of 2014 it became clear that in Kyrgyzstan and Tajikistan, which were not supposed to take Turkmen gas, there would be problems with the establishment of joint ventures with Chinese firms for the construction and further operation of the gas pipeline. The last meeting of Kyrgyz and Chinese representatives on the D pipeline was held in December 2015, from which it can be concluded that the PRC does not put this project among the priority ones. China National Petroleum Corporation and Uzbekneftegaz have postponed the construction of the D pipeline indefinitely [32].

Secondly, a huge impact on the economy of Turkmenistan is due to Russia's refusal in the beginning of last year from the import of Turkmen gas and the suspension of gas supplies from Turkmenistan to Iran earlier this year due to disagreements over the terms of the contract.

The importance of cooperation with the Russian company for Turkmenistan was very significant, because even with the volume of purchases of 4 billion cubic meters per year (in 2015) at a price of $\$ 240$. per thousand cubic meters. $m$ the income of the Turkmen side was about 960 million dollars [33].

Until the 2010's. the main buyer of Turkmen gas was not China, but Russia, which is connected with the republic built in the Soviet period by the Central Asia-Center gas pipeline. The formal reason for the cooling of Russian-Turkmen «gas» relations was an explosion on the Central Asia-Center gas pipeline in April 2009, in which Gazprom and Turkmengaz accused each other. In fact, the parties could not agree on the purchase price of Turkmen gas. After the beginning of the economic crisis, the price of $\$ 375$ per thousand cubic meters. m. was high for Russia, for which the Russian Federation offered Turkmenistan to review the terms of the contract, but it refused.

As a result, Russia's purchase of Turkmen gas stopped altogether, and resumed only from 102
January 2010. But if earlier, Gazprom bought from Turkmenistan up to 50 billion cubic meters. m gas, then from 2010 - 10-11 billion cubic meters. m per year. By mid-2015, Gazprom filed a lawsuit against Turkmengaz against the Stockholm Arbitration, demanding compensation for losses incurred due to too high a purchase price of $\$ 5$ billion. The case was adjourned. Nevertheless, from January 1, 2016, Gazprom ahead of schedule terminated the contract with Turkmengaz, and in September the deputy chairman of the Gazprom board, Alexander Medvedev, said that until the end of 2018, the company would not buy gas from Turkmenistan. Now Gazprom has contracts with Kazakhstan and Uzbekistan, for which it pays 140 dollars for these cubic meters. Thus, Turkmenistan has serious price competition in the region [34].

Thirdly, Turkmenistan's growing credit dependence on the PRC. According to independent researchers, Turkmenistan's external debt to China is in the range of $\$ 12$ billion. [35]. Of these funds, the bulk belongs to the fuel and energy sector ( $\$ 8.1$ billion is only loans for the development of Galkynysh). For comparison, according to available estimates, the total volume of investments by PRC in Kazakhstan, Turkmenistan and Uzbekistan reached \$30 billion by 2015 .

The specificity of trade relations between Turkmenistan and China consists in the domination of energy supplies in China and the small volume of imports from China. The latter circumstance is connected, among other things, with the peculiarities of Turkmenistan's position in the transport and trade relation: a significant volume of Chinese imports to Kazakhstan and Kyrgyzstan is associated with their significant transit potential and access to large sales markets.

In June 2017, the President of Turkmenistan Gurbanguly Berdimuhamedov met with the Chairman of the People's Republic of China, Xi Jinping, during his working visit to Kazakhstan. During the meeting, the leaders discussed the prospects for cooperation between the PRC and Turkmenistan [37]. The leaders of the two states noted the progressive dynamics of the development of the Turkmen-Chinese dialogue. The heads of 
Turkmenistan and China exchanged views on key areas of strategic cooperation, confirming their readiness to build up the economic partnership, taking into account its colossal potential, national interests and a common vision for the future of the Asian region.

Turkmenistan regards China as its main gas market and is preparing to increase exports in this direction. In 2016, Turkmenistan plans to increase gas production by $9 \%$, to 83.8 billion $\mathrm{m} 3$, for export will be supplied about 48 billion cubic meters of gas. Under an agreement signed between Turkmengaz and CNPC in June 2012, by the end of 2021 Turkmenistan will have to supply 65 billion cubic meters of gas to China annually [38].

Speaking about topical aspects of regional and international policies of mutual interest, the President of Turkmenistan and the Chairman of the People's Republic of China expressed their mutual support for the important international initiatives put forward by both countries aimed at creating a solid foundation for a peacefree conflict in the 21 st century, strengthening friendship and mutual understanding between peoples and states. To date, there are three lines of the Turkmenistan-Uzbekistan-KazakhstanChina gas pipeline, which allow Turkmenistan to export up to 40 billion cubic meters of natural gas to China every year. In the future, the countries plan to continue to partner in the widest range of areas, including the trade and economic sector, transport, communications, textile and chemical industries, and construction.

The main component of cooperation in the energy sector is partnership in the gas sector. The priority task remains the successful implementation of the grandiose project of the XXI century - the construction of the Turkmenistan-China gas pipeline, which now provides long-term supplies of Turkmen gas to the China [39].

Chairman of the People's Republic of China Xi Jinping stressed that China today is Turkmenistan's main partner in the energy sector, highly appreciating the achieved level of long-term cooperation in the gas industry. He also noted the solid potential for interaction in the transport sector, calling the perspective route Turkmenistan-Kazakhstan-China very promising.

Discussing this topic, the sides noted the accumulated experience of joint work in the field of railway transport. At the same time, the need was stressed to strengthen interaction in transport logistics in order to improve the efficiency of the transit corridors connecting China with Europe, the Middle East and Mediterranean regions through the territory of Turkmenistan.

An exchange of views took place on the prospects for expanding the interstate partnership. In this context, President Gurbanguly Berdimuhamedov stressed that Turkmenistan considers its participation in the "World Expo2017" in Astana as a kind ambassador for the sake of general progress and prosperity. In recent years, bilateral relations have been intensively developing in the cultural and humanitarian sphere, in particular, in the field of education: hundreds of students from Turkmenistan receive higher education in China.

Thus, in the bilateral relations between Turkmenistan and the PRC, there are unresolved contradictions, contradictions and problems, such as the economic crisis in Turkmenistan, its economic dependence on China, but both sides are interested in continuing cooperation both in the energy sector (in particular, the construction of the fourth pipeline D and development of alternative energy sources), and in the trade and economic sphere, transport and cultural and humanitarian.

At present, Turkmenistan and China have strong economic relations based mainly on the purchase of Turkmen gas, Chinese investments in the development of gas production and gas transportation infrastructure. Both sides are interested in developing bilateral relations and extracting maximum benefits from them.

China is Turkmenistan's largest foreign economic partner, and the Chinese organization CNPC is the largest exporter of gas and, at the same time, the largest investor in the field of engineering and technical services in oil fields: drilling wells, well logging, construction of ground facilities for oil and gas fields, In the same 
area, SINOPEC is working to repair and maintain wells in gas and oil fields

The contractual framework basically includes agreements between CNPC on the part of the PRC and Turkmengaz as the representative of Turkmenistan. According to the agreements of June 24, 2009, Turkmenistan pledged to supply gas to China in the amount of up to 40 billion cubic meters a year after the first phase of the Trans-Asian gas pipeline was put into operation within the next 30 years. To date, the A, B and $\mathrm{C}$ pipelines are operating successfully. An agreement was also signed on the issue of a $\$ 4$ billion loan by the Development Bank of China. on the development of gas fields of the South Yolotan Group.

However, there are some contradictions in bilateral relations.

First, Turkmenistan is experiencing the worst economic crisis in 25 years, which significantly affects both the development of the country's economy and the price policy. It plays a significant role, as in the region there is a fierce competition in the sphere of trade in energy resources.

Second, Russia's policy in the region. Due to the severance of trade relations with the Russian Federation, Turkmenistan is losing a potential market. In addition, buying gas and oil from Kazakhstan and Uzbekistan at a low price, Russia makes Turkmenistan uncompetitive, forcing to set low prices.

And, finally, an increase in the economic and financial-credit dependence of Turkmenistan on the PRC. Having a huge external debt to China, Turkmenistan can not abandon Chinese investment, since they are their main international partners, but does not want to increase dependence. And yet, despite the existing problems, both sides are ready to develop and deepen cooperation not only in the energy sector, but in many others. In the energy sector, the priority is the trade in oil and gas, as well as the development of alternative energy sources.

\section{Бібліографічні посилання}

1. BP Statistical Review of World Energy June 2014. BP: Energy economics. London, 2014. Access mode: https://www. bp.com/content/dam/bp-country/de_de/PDFs/brochures/BP-statistical-review-of-world-energy-2014-full-report.pdf

2. В Астане состоялась встреча председателя КНР Си Цзиньпина с президентом Туркменистана Г.Бердымухамедовым [Electronic source]. Embassy of the People's Republic of China in Turkmenistan. 2017. Access mode: http:// tm.chineseembassy.org/rus/ztgx/t1469243.htm

3. Чрезвычайный и Полномочный Посол Китайской Народной Республики в Туркменистане господин У Хунбинь дал интервью газете» Нейтральный Туркменистан»[Electronic source]. Embassy of the People s Republic of China in Turkmenistan. 2009. Access mode: http://tm.chineseembassy. org/rus/ztgx/t579358.htm

4. Paramonov V., Strokov A. China in Central Asia: energy interests and energy policy [Electronic source]. Central Asia and the Caucasus. 2010. №3. Access mode: http://cyberleninka.ru/article/n/china-in-central-asia-energy-interests-andenergy-policy

5. China`s global strategy (2013-2023) [Electronic source]. SIIS Project Team. 2013. Access mode: http://en.siis.org.cn/ uploadfile/2013/1019/20131019065456733

6. Natural Gas for China: Uncertainty for Markets [Electronic source]. M.Ratner, G.Nelson, S.Lawrence. Congressional Research Service. 2016. Access mode: https://fas.org/sgp/crs/row/R44483.pdf

7. Turkmenistan - Oil and Natural Gas Refining [Electronic source]. Turkmenistan Country Commercial Guide. 2017. Access mode: https://www. export.gov/article?id=Turkmenistan-Oil-and-Natural-Gas-Refining

8. 28th Meeting of the Energy Charter Conference [Electronic source]. International Energy Charter. 2017. Access mode: http://www.energycharter.org/who-we-are/energy-charter-conference/meetings/28th-meeting-of-the-energy-charterconference/

9. The President of Turkmenistan delivered a speech during the Forum of Energy Charter on "Reliable and stable transit of energy carries" [Electronic source]. Energy Charter Conference. 2017. Access mode: http://www.energyashgabat2017. gov.tm/en/news/14

10. U.S. Energy Information Administration. Caspian Sea Region [Electronic source]. Independent Statistics and Analysis. 2013. Access mode: http://www.eia.gov/countries/analysisbriefs/Caspian_Sea/caspian_sea.pdf

11. Joint Statement between Japan and Turkmenistan on the new Partnership [Electronic source]. 2013. Access mode: http://www.mofa.go.jp/ mofaj/files/000013896.pdf 
12. China obtains 200 billion cubic meters of gas piped from Central Asia [Electronic source]. Energy Market Price. 2017. Access mode: http://www.energymarketprice.com/energy-news/china-obtains-200-billion-cubic-meters-of-gaspiped-from-central-asia

13. Trans Asia Gas Pipeline from Turkmenistan to China [Electronic source]. IPLOCA Convention. 2012. Access mode: http://www.iploca. com/platform/content/element/14392/4AndreasKohler.pdf

14. Turkmenistan starts work on gas link to Afghanistan, Pakistan, India [Electronic source]. Reuters. 2015. Access mode: https://uk.reuters.com/article/turkmenistan-gas-pipeline/turkmenistan-starts-work-on-gas-link-to-afghanistan-pakistanindia-idUKKBN0TW05Q20151213

15. Ramtanu M. New Silk Road: Turkmenistan Emerges into the World of China`s Belt and Road Initiative [Electronic source]. Exclusive Intelligence Review. 2017. Access mode: https://www.larouchepub.com/ eiw/public/2017/ eirv44n02-20170113/17-22_4402.pdf

16. Туркменистан представляет на ЭКСПО-2017 свой энергетический потенциал [Electronic source]. Государственной информационное агентство Туркменистана «Туркменистан сегодня». 2017. Access mode: http://tdh. gov.tm/news/articles.aspx\&article $7449 \&$ cat11

17. OSCE events in Turkmenistan address energy issues [Electronic source]. Official Site of OSCE. 2017. Access mode: http://www.osce.org/centre-in-ashgabat/312586

18. Парамонов В., Строков А., Столоповский О. Экономическое присутствие Китая в Туркменистане [Electronic source]. 2009. Access mode: http://www.easttime.ru/ analitic/1/2/702.html

19. Сыроежкин К.Л. Присутствие Китая в энергетическом секторе Центральной Азии. Центральная Азия и Кавказ. 2010. № 1. С. 37. Access mode: https://cyberleninka.ru/article/ v/prisutstvie-kitaya-v-energeticheskom-sektoretsentralnoy-azii

20. Сотрудничество по газу с Центральной Азией [Electronic source]. Официальный сайт компании CNPC. Access mode: http://www.cnpc.com.cn/ru/zytrqgdzt/zytrqgdzt_2.shtml

21. Туркменистан обеспечит поставку до 40 млрд. куб. м. природного газа в Китай [Electronic source]. Embassy of the People's Republic of China in Turkmenistan. 2009. Access mode: http://tm.chineseembassy.org/ rus/jmwl/t579352.htm 22. Gas supply via Turkmenistan-China pipeline increases [Electronic source]. Trend.az. 2016. Access mode: https:// en.trend.az/casia/turkmenistan/2522158.html

23. Galkynysh Gas Field, Turkmenistan [Electronic source]. Hydrocarbons-technology. 2017. Access mode: http://www. hydrocarbons-technology.com/projects/galkynysh-gas-field-turkmenistan/

24. Гасанов Г. Китай - один из важнейших стратегических партнёров Туркменистана [Electronic source]. Академия наук Туркменистана. 2017. Access mode: http://science.gov.tm/news/20171011news-2017-10-11-3/

25. Financial Statements [Electronic source]. Annual Report of CNPC. 2015. Access mode: http://www.cnpc.com.cn/en/2 014enbv/201504/1a93feff260b477f 999ab802945d38e2/ files/4218dd05ada64779bbb375fcea4a3534.pdf

26. Проект разведки и разработки природного газа [Electronic source]. Официальный сайт компании CNPC. Access mode: http://www.cnpc.com.cn/ru/tkmst/tkmst_index.shtml

27. Проект строительства завода по обработке природного газа на правом берегу Амударьи [Electronic source]. Официальныій сайт компании СNPC. Access mode: http://www.cnpc.com.cn/ru/tkmst/tkmst_index.shtml

28. Financial Statements [Electronic source]. Annual Report of SINOPEC. 2011. Access mode: http://www.sinopecgroup. com/group/en/Resource/ pdf/GroupAnnualReport2011en.pdf

29. Bohr A. Turkmenistan: Power, Politics and Petro-Authoritarianism [Electronic source]. The Royal Institute of International Affairs. 2016. Access mode: https://www.chathamhouse.org/sites/files/chathamhouse/ publications/ research/2016-03-08-turkmenistan-bohr.pdf

30. Состоялся первый туркмено-китайский бизнес-форум [Electronic source]. Гундогар. 2010. Access mode: http:// www.gundogar.org/

31. Ипполитов И.В. Китайско-туркменские отношения: от взаимной выгоды к неравному партнерству? [Electronic source]. Проблемы наииональной стратегии. 2017, №3(42). С. 11. Access mode: https://riss.ru/images/pdf/ journal/2017/3/08.pdf

32. Узбекистан и КНР заморозили строительство четвертого газопровода [Electronic source]. Новостное агентство Sputnik. 2017. Access mode: http://ru.sputnik-tj.com/economy/20170302/1021799826/gazoprovod-uzbekistantadzhikistan-kitay.html

33. Кувакин И. «Газпром» отказался от поставок газа из Туркмении [Electronic source]. РБК. 2016. Access mode: http://www.rbc.ru/business/04/01/2016/568a60d89a79477ae3bf88fc

34. Шустов А. Туркменистан сменил зависимость от России на Китай [Electronic source]. Евразия Эксперт. 2016. Access mode: http://eurasia.expert/turkmenistan-smenil-zavisimost-ot-rossii-na-kitay/

35. Tajikistan, Turkmenistan Submit to Chinese Capture [Electronic source]. News block Eurasianet. 2016. Access mode: http://www.eurasianet.org/ node/79401 
36. Bhadrakumar M.K. Why Central Asia should be the exception to Modi's strategy of trying to match China? [Electronic source]. Scroll in. 2015. Access mode: http://scroll.in/article/738717/why-central-asia-should-be-the-exception-to-modisstrategy-of-trying-to-matchchina

37. Товарооборот Туркменистана с Китаем в денежном эквиваленте значительно сократился [Electronic source]. Хроника Туркменистана. 2017. Access mode: https://www.hronikatm.com/2017/01/tovarooborot-turkmenistana-skitaem-v-denezhnom-ekvivalente/].

38. Китай получил 138,6 млрд м3 газа из Туркменистана по сети газопроводов Центральная Азия-Китай [Electronic source]. Форум Нефтегаз. 2016. Access mode: https://neftegaz.ru/news/view/149466-Kitay-poluchil-1386-mlrd-m3gaza-iz-Turkmenistana-po-seti-gazoprovodov-Tsentralnaya-Aziya-Kitay

39. Главы Туркменистана и Китая обсудили перспективы расширения межгосударственного партнёрства [Electronic source]. Информационный портал Туркменистана. 2017. Access mode: https://turkmenportal.com/ blog/10968/glavy-turkmenistana-i-kitaya-obsudili-perspektivy-rasshireniya-mezhgosudarstvennogo-partnerstva 